Artikel Penelitian

\title{
Hubungan Near-Work dengan Miopia pada Siswa SD Negeri Percobaan Kelas 5 dan 6
}

\author{
Indah A.R BR Tobing ${ }^{1}$, Kemala Sayuti ${ }^{2}$, Afdal $^{3}$
}

\begin{abstract}
Abstrak
Miopia adalah kelainan refraksi yang disebabkan oleh ketidakmampuan komponen optik untuk memfokuskan cahaya tepat di retina dalam keadaan mata tidak berakomodasi. Keadaan ini sering dijumpai pada anak usia sekolah. Lebih dari $60 \%$ miopia merupakan miopia onset dini yang timbul pada usia 7 hingga 16 tahun. Salah satu faktor resiko lingkungan yang berhubungan dengan miopia adalah banyaknya melakukan kegiatan near-work. Tujuan penelitian ini adalah menentukan hubungan antara near-work dengan miopia pada anak usia sekolah dasar. Penelitian bersifat analitik dengan desain cross sectional. Pengambilan sampel menggunakan teknik total sampling, sehingga diperoleh 94 orang. Pengambilan data dilakukan dengan menggunakan kuesioner yang diisi oleh murid dan near-work diary yang diisi oleh orang tua murid. Pemeriksaan refraksi dilakukan secara subjektif dengan menggunakan Snellen chart dan trial lens. Pengolahan data dilakukan dengan uji chi-square secara komputerisasi. Hasil penelitian menunjukkan bahwa terdapat hubungan antara kebiasaan membaca dengan kejadian miopia $(p=0,000)$. Tidak terdapat hubungan bermakna antara kebiasaan menonton televisi $(p=0,579)$, bermain video game $(p=0,205)$ dan menggunakan komputer $(p=0,084)$ dengan kejadian miopia. Simpulan studi ini ialah terdapat hubungan yang sangat bermakna antara kebiasaan membaca dengan myopia, tetapi tidak terdapat hubungan yang bermakna antara menonton televisi, bermain videogame, dan menggunakan komputer dengan kejadian miopia.
\end{abstract}

Kata kunci: miopia, near-work, anak usia sekolah

\begin{abstract}
Myopia is a refractive error caused by the inability of optical components to focus the lights into the retina in a non accommodating eye. This condition is often seen in school-aged children. More than $60 \%$ of myopia is early-onset which occurs between 7 to 16 years of age. One of the environmental risk factors that contribute to the development of myopia is near-work activities. The objective of this study was to determine the relationship between near-work and myopia in elementary school-aged children. This research was an analytic study with cross sectional design. There were 94 subjects that was chosen using by total sampling method. The data was obtained using self-administered questionnaire and a near-work diary completed by parents. Measurement of refractive error was done using Snellen chart and subjective test using trial lens. The data processing used chi-square test by computerized system. The result showed there was relationship between reading and myopia $(p=0.000)$. No significant relationship between watching television ( $p=0.578)$, playing videogame $(p=0.205)$, using computer $(p=0.084)$ and myopia. The conclusion is the significant relationship between reading on myopia, but there is no significant relationship watching television, playing videogame, using computer on myopia.
\end{abstract}

Keywords: myopia, near-work, school-aged children

Affiliasi penulis: Prodi Profesi Dokter FK Unand (Fakultas Kedokteran Universitas Andalas Padang), 2. Bagian Mata FK Unand/RSUP Dr. M.Djamil Padang, 3. Bagian Anak FK Unand.
Korespondensi : Indah A.R BR Tobing, Email: sigembong@gmail.com, Telp: 08566399199 


\section{PENDAHULUAN}

Analisis WHO menunjukkan kelainan refraksi yang tidak terkoreksi merupakan penyebab utama darigangguan penglihatan di dunia dan miopia menempati presentasi tertinggi. ${ }^{1,2}$ Miopia merupakan kelainan refraksi yang disebabkan oleh ketidak mampuan komponen optik untuk memfokuskan cahaya tepat di retina dalam keadaan mata tidak berakomodasi. ${ }^{3}$

Departemen Kesehatan RI melalui Dirjen Bina Upaya Kesehatan dr. Supriyantoro, SpP MARS mengatakan bahwa kelainan refraksi merupakan penyebab kebutaan di Indonesia dengan prevalensi sebesar $22,1 \%$ dari total populasi, dan $15 \%$ diantaranya diderita oleh anak usia sekolah (5-19 tahun). ${ }^{4}$ Penelitian yang dilakukan di Sumatera menemukan prevalensi miopia sebesar $26,1 \%$. Nilai ini lebih besar dari prevalensi miopia pada ras kulit putih, tetapi lebih rendah bila dibandingkan dengan Negara lain di Asia contohnya Singapura. ${ }^{5}$ Seiring dengan meningkatnya derajat keparahan miopia, penderita miopia mempunyai resiko lebih tinggi untuk mengalami komplikasi yang berpotensi mengakibatkan kebutaan seperti ablasio retina, glaukoma, katarak prematur dan degenerasi makular. ${ }^{6}$

Faktor genetik dan lingkungan berperan penting dalam proses terjadi dan progresivitas miopia. Studi terbaru menunjukkan bahwa tingginya prevalensi miopia lebih disebabkan oleh paparan faktor lingkungan dibandingkan dengan adanya kerentanan genetik. Hal ini didukung oleh ditemukan perbedaan signifikan dari prevalensi miopia dalam satu kelompok etnis yang sama namun dengan kondisi lingkungan yang berbeda. ${ }^{1}$

Near-work telah banyak diteliti sebagai faktor lingkungan utama yang berperan dalam proses terjadinya dan progresivitas miopia. ${ }^{7}$ Near-work adalah kegiatan yang membutuhkan tingkat akomodasi tinggi seperti membaca, menulis, menggunakan komputer dan menonton televisi. ${ }^{8}$

SD Negeri Percobaan Padang merupakan SD bertaraf internasional dan mempunyai akreditasi $A$. Tingginya beban akademik pada siswa SD Negeri Percobaan Padang akan meningkatkan paparan terhadap near-work. Hal ini berpotensi meningkatkan resiko menderita miopia. Penelitian ini bertujuan untuk menentukan hubungan antara near-work dengan miopia pada siswa SD Negeri Percobaan Padang kelas 5 dan 6.

\section{METODE}

Penelitian ini menggunakan metode cross sectional dimana near-work sebagai faktor risiko dan miopia pada anak usia sekolah sebagai efek yang diteliti. Waktu pelaksanaan adalah bulan Januari 2014 hingga April 2014. Populasi terjangkau adalah murid SD Negeri Percobaan kelas 5 dan 6pada tahun 2013. Kriteria inklusi adalah responden yang hadir pada saat pengumpulan data. Kriteria eksklusi adalah responden yang sedang menderita infeksi mata luar, seperti konjungtivitis. Sampel dalam penelitian ini ditentukan dengan caratotal sampling.

Data didapat dengan cara wawancara langsung menggunakan kuesioner mengenai near-work dan diisi langsung oleh responden dan near-work diary yang diisi oleh orang tua responden. Pengukuran visus menggunakan Snellen chart dan dilanjutkan dengan pengukuran derajat miopia secara subjektif dengan menggunakan trial lens.

Miopia didefenisikan dengan derajat SE (spherical equivalent) $\leq-0,5 \mathrm{D}$ minimal pada satu mata yang diperiksa. Nilai -0,5 D diambil sebagai cutoff point karena mempunyai nilai sensitivitas yang tinggi dan telah bermanifestasi secara klinis. ${ }^{9}$

Near-work merupakan kumpulan dari beberapa kegiatan diantaranya membaca pada jarak $<30 \mathrm{~cm}$ dan $>2$ jam/hari, menonton televisi pada jarak $<2 \mathrm{~m}$ dan $>2$ jam/hari, menggunakan komputer pada jarak $>60 \mathrm{~cm}$ dan $>8$ jam/hari, bermain videogame pada jarak $<2 \mathrm{~m}$ dan $>2$ jam/hari. ${ }^{10}$ Near-work diary digunakan sebagai acuan dalam menilai kebiasaan anak dalam melakukan near-work. Sebelum pengisian kuesioner peneliti memberikan pengarahan dalam pengisian kuesioner dan menjelaskan kembali apabila ada responden yang mengalami kesulitan dalam pengisian kuesioner.

Data yang terkumpul dalam penelitian ini akan dicatat dan diolah lebih lanjut untuk dilakukan uji kemaknaan chi-square untuk melihat hubungan antara dua variable yaitu variable bebas dan terikat. Jika 
terdapat perbedaan bermakna $(p<0,05)$ dan tidak ada perbedaan bermakna $(p>0,05)$

HASIL

Tabel 1. Distribusi frekuensi kejadian miopia

\begin{tabular}{ccc}
\hline Visus & $\mathrm{f}$ & $\%$ \\
\hline Normal & 48 & 54,5 \\
Miopia & 40 & 45,5 \\
Jumlah & 88 & 100 \\
\hline
\end{tabular}

Tabel 2. Distribusi frekuensi miopia terhadap usia responden

\begin{tabular}{ccccccccc}
\hline & \multicolumn{1}{c}{ usia responden } \\
& $\mathbf{1 0}$ tahun & \multicolumn{1}{c}{$\mathbf{1 1}$ tahun } & \multicolumn{1}{c}{$\mathbf{1 2}$ tahun } & \multicolumn{1}{c}{$\mathbf{1 3}$ tahun } \\
\cline { 2 - 10 } & $\mathbf{f}$ & $\%$ & $\mathbf{f}$ & $\%$ & $\mathbf{f}$ & $\%$ & $\mathbf{f}$ & $\%$ \\
\hline normal & 8 & 16,7 & 19 & 39,6 & 19 & 39,6 & 2 & 4,2 \\
miopia & 6 & 15 & 19 & 47,5 & 15 & 37,5 & 0 & 0 \\
\hline total & 14 & 15,9 & 38 & 43,2 & 34 & 38,6 & 2 & 2,3 \\
\hline
\end{tabular}

Tabel 3. Hubungan membaca $<30 \mathrm{~cm}$ dan $>2$ jam/hari dengan miopia

\begin{tabular}{|c|c|c|c|c|c|c|c|c|}
\hline & \multicolumn{2}{|c|}{ miopia } & \multicolumn{2}{|c|}{ normal } & \multicolumn{2}{|c|}{ total } & $\begin{array}{l}\text { OR } \\
(95 \%) \\
\text { CI }\end{array}$ & $\mathbf{p}$ \\
\hline & $f$ & $\%$ & $f$ & $\%$ & $f$ & $\%$ & & \\
\hline ya & 29 & 72,5 & 11 & 27,5 & 40 & 100 & & \\
\hline tidak & 11 & 22,9 & 37 & 77,1 & 48 & 100 & 8,9 & $<0,001$ \\
\hline total & 40 & 45,5 & 48 & 54,5 & 88 & 100 & & \\
\hline
\end{tabular}

Tabel 4. Hubungan menonton televisi $<2 \mathrm{~m}$ dan $>2$ jam/hari dengan miopia

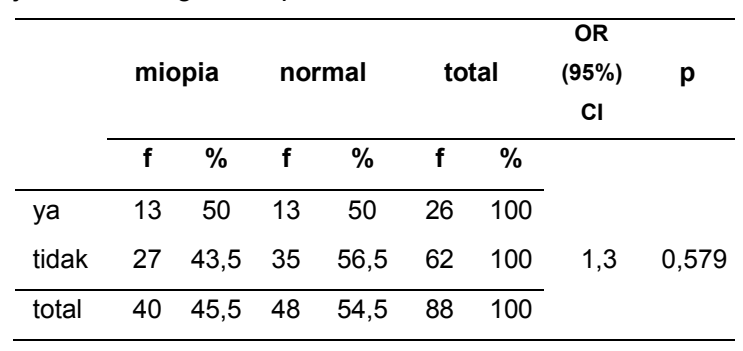

Tabel 5. Hubungan Bermain Video game $<2 \mathrm{~m}$ dan $>$ 2 jam/ hari dengan Miopia

\begin{tabular}{lcccccccc}
\hline & miopia & normal & total & $\begin{array}{c}\text { OR } \\
\mathbf{( 9 5 \% )} \\
\text { Cl }\end{array}$ & $\mathbf{p}$ \\
\cline { 2 - 6 } & $\mathrm{f}$ & $\%$ & $\mathrm{f}$ & $\%$ & $\mathrm{f}$ & $\%$ & & \\
\hline ya & 15 & 55,6 & 12 & 44,4 & 27 & 100 & & \\
tidak & 25 & 41,0 & 36 & 59,0 & 61 & 100 & 1,8 & 0,205 \\
total & 40 & 45,5 & 48 & 54,5 & 88 & 100 & & \\
\hline
\end{tabular}

Tabel 6. Hubungan menggunakan komputer $<60 \mathrm{~cm}$ dan $>8$ jam/hari dengan miopia

\begin{tabular}{|c|c|c|c|c|c|c|c|c|}
\hline & \multirow{2}{*}{\multicolumn{2}{|c|}{ miopia }} & \multirow{2}{*}{\multicolumn{2}{|c|}{ normal }} & \multirow{2}{*}{\multicolumn{2}{|c|}{ total }} & \multirow{2}{*}{$\begin{array}{c}\text { OR } \\
(95 \%) \\
\mathrm{Cl}\end{array}$} & \multirow{3}{*}{$\mathbf{p}$} \\
\hline & & & & & & & & \\
\hline & $f$ & $\%$ & $f$ & $\%$ & $f$ & $\%$ & & \\
\hline yа & 7 & 77,8 & 2 & 22,2 & 9 & 100 & & \\
\hline tidak & 27 & 45 & 33 & 55 & 60 & 100 & 0,2 & 0,084 \\
\hline total & 34 & 49,3 & 35 & 50,7 & 69 & 100 & & \\
\hline
\end{tabular}

Pada penelitian ini ditemukan hubungan yang sangat bermakna antara membaca dengan jarak < 30 $\mathrm{cm}$ dan $>$ jam/hari dengan kejadian miopia $(p<0,001)$. Pada penelitian ini tidak ditemukan hubungan yang bermakna antara menonton televisi, bermain video game dan menggunakan komputer dengan kejadian miopia $(p>0,05)$.

\section{PEMBAHASAN}

Pada penelitian yang dilakukan pada siswa kelas 5 dan 6 di SD Negeri Percobaan Padang, ditemukan angka kejadian miopia sebanyak 45,5\%. Nilai ini lebih tinggi bila dibandingkan dengan penelitian yang dilakukan di Tangerang pada tahun 2011 pada siswa SD Islam Rumaha kelas 5 dan 6. Pada penelitian tersebut didapatkan angka kejadian miopia sebesar $42,2 \%{ }^{11}$ Penelitian lain yang dilakukan pada 7 SD di daerah Pondok Ranji Ciputat didapatkan sebanyak $57,3 \%$ dari total 89 responden kelas 4 dan 6 menderita miopia. ${ }^{12}$

Pada penelitian ini ditemukan sebagian besar anak yang menderita miopia adalah miopia derajat 
ringan. Miopia onset dini atau school myopia merupakan bentuk miopia yang paling sering ditemui dan sebagian besar merupakan miopia derajat ringan. Namun semakin dini usia dari onset miopia dan tingginya derajat miopia berhubungan dengan progresivitas miopia yang lebih cepat. ${ }^{13}$ Oleh sebab itu tingginya angka kejadian miopia yang ditemukan pada siswa kelas 5 dan 6 pada penelitian ini merupakan hal yang harus diperhatikan.

Pada penelitian ini juga ditemukan miopia paling banyak diderita oleh anak berusia 11 tahun, yaitu sebesar $47,5 \%$. Pada usia 12 tahun ditemukan sebesar $38,6 \%$, pada usia 10 tahun sebesar $15,9 \%$ dan pada usia 13 tahun sebesar 2,3\%. Hasil penelitian lain yang dilakukan oleh Fan et al.menemukan adanya hubungan antara peningkatan usia anak dengan kejadian miopia. Anak berusia 11 tahun hampir 15 kali beresiko lebih besar untuk menderita miopia dibandingkan dengan anak berusia dibawah 17 tahun (OR 14,81; 95\% Cl = 14,17-15,48). ${ }^{14}$ Perbedaan dari hasil yang ditemukan dapat diakibatkan karena sebaran sampel yang tidak merata untuk tiap usia pada penelitian ini sehingga tidak dapat memperlihatkan hubungan antara miopia dengan peningkatan usia.

\section{Hubungan Near-Work dengan Miopia}

Dalam penelitian ini ditemukan bahwa kegiatan near-work yang mempunyai hubungan yang sangat bermakna dengan miopia adalah kebiasaan membaca dengan jarak $<30 \mathrm{~cm}$ dan durasi $>2$ jam/hari $(p<0,001$ OR 8,$9 ; 95 \% \mathrm{Cl}=3,37-23,31)$. Hasil yang sama ditemukan pada penelitian yang dilakukan oleh Ip et al pada 2353 anak usia sekolah di Australia dengan rata-rata usia 12 tahun. Dari penelitian tersebut ditemukan bahwa jarak baca $<30 \mathrm{~cm}$ $(p<0,001$ OR 2,$5 ; 95 \% \mathrm{Cl}=1,7-4,0)$ dan membaca dengan durasi $>30$ menit mempunyai hubungan yang signifikan terhadap kejadian miopia $(p<0,02$ OR 1,5 ; $95 \% \mathrm{Cl}=1,05-2,1) .^{15}$

Hal ini sesuai dengan teori yang menyebutkan bahwa kebiasaan membaca dengan jarak baca yang dekat dalam waktu yang lama dapat menjadi sumber untuk terjadinya hyperopic defocus pada mata. Keadaan ini akan menginduksi respon akomodatif dan mengakibatkan pemanjangan dari sumbu aksial mata. $^{15}$

Pada penelitian ini tidak ditemukan hubungan yang bermakna antara jarak dan durasi dalam melakukan kegiatan near-work lain seperti menonton televisi $(p=0,579)$, bermain videogame $(p=0,205)$, dan menggunakan komputer $(p=0,084)$. Penelitian yang dilakukan oleh Ip et al juga menemukan hubungan yang lemah antara waktu yang digunakan dalam bermain videogame dengan miopia $(p=0,09) .{ }^{15}$

Hal ini dapat disebabkan karena jarak yang digunakan dalam menonton televisi, bermain videogamedan menggunakan komputer lebih jauh dibandingkan dengan jarak yang digunakan dalam membaca, sehingga usaha akomodasi untuk membaca lebih besar. $^{16}$ Parssinen dan Lyrra mengatakan bahwa terdapat gerakan sakade konstan pada saat membaca yang memberikan stres terusmenerus kepada otot mata. Tingginya stres yang diberikan kepada otot mata tersebut berhubungan dengan penipisan dinding sklera. ${ }^{17}$

\section{SIMPULAN}

Terdapat hubungan yang sangat bermakna antara kebiasaan membaca dengan kejadian myopia.

Tidak terdapat hubungan bermakna antara kegiatan near-work lain seperti menonton televisi, bermain videogame dan menggunakan komputer dengan kejadian miopia.

\section{DAFTAR PUSTAKA}

1. French AN, Ashby RS, Morgan IG, Kathryn A Rose. Time outdoors and prevention of myopia. Experimental Eye Research. 2013;114(1):58-68.

2. Myrowitz, EH. Juvenile myopia progression, risk factors and intervention.Saudi Journal of Opthalmology. 2012;26(3):293-7.

3. Wakode NS, Wakode SL, Ksheersagar DD. Risk factors for myopia in medical student. International Journal of Recent Trends in Science and Technology. 2013;8(1):09-11.

4. Departemen Kesehatan RI. Mata sehat di segala usia untuk peningkatan kualitas hidup masyarakat 
Indonesia. 2012. (diunduh 28 Februari 2014). Tersedia dari: URL: HYPERLINK http://www. depkes.go.id/index.php?vw=2\&id=2082

5. Chen KU, Hsi E, Hu CY, Chou WW, Ling CU, et al. MicroRNA-328 may influence myopia development by mediating the PAX6 gene. Investigative Ophthalmology and Visual Science. 2012;53(6): 2732-9.

6. Mutti DO, Mitchell GL, Moeschberger ML, Jones LA, Zadnik K. Parental myopia, near-work, school achievement, and children's refractive error. Investigative Ophthalmology and Visual Science. 2002;43(12):3633-40.

7. Ciuffreda KJ, Vasuvedan B. Nearwork-induced transient myopia (NITM) and permanent myopia is there a link ?. Investigative Ophthalmology and Visual Science. 2008;28(2):103-14.

8. Jones-Jordan LA, Sinnott LT, Cotter SA, Kleinstein $\mathrm{RN}$, Manny RE, et al.Time outdoors, visual activity and myopia progression in juvenile onset myopes. Investigative Ophthalmology and Visual Science. 2012;53(11):7169-75.

9. Luo HD, Gazzard G, Shankar A, Tan DTH, Saw, SM. Defining myopia using refractive error and uncorrected logMAR visual acuity > 0,3 from 1334 Singapore school children ages 7-9 years. British Journal of Ophthalmology. 2006;90(3):362-6.

10. Fachrian $D$, Rahayu $A B$, Naseh $A J$, Rerung $N$, Pramesti $M$, et al. Prevalensi kelainan tajam penglihatan pada pelajar SD "X" Jatinegara Jakarta Timur. Majalah Kedokteran Indonesia. 2009;59(6):7-11.
11. Sastraningrat, M. Gambaran tingkat pengetahuan dan sikap siswa SD Islam Ruhama Cireundeu kelas 5 dan 6 terhadap miopia dan faktor yang mempengaruhinya tahun 2011 (skripsi). Jakarta: Universitas Islam Negeri Syarif Hidayatullah; 2011.

12. Rahmadhini. Prevalensi miopia pada siswa sd kelas 4 dan 6 di kelurahan pondok ranji ciputat tahun 2009 (skripsi). Jakarta: Universitas Islam Negeri Syarif Hidayatullah;2009.

13. Wu PC, Tsai CL, Wu HL, Yang YH, Kuo HK. Outdoor activity during class recess reduces myopia onset and progression in school children. American Academy of Ophthalmology. 2013; 120 (5):1-6.

14. Fan D, Lam D, Lam R, Lau J, Chong K, Cheung E, et al. Prevalence, incidence, and progression of myopia of schoolchildren in Hong Kong. Investigative Ophthalmology and Visual Science. 2004;45(4):1071-5.

15. Ip JM, Saw SM, Rose KA, Morgan IG, Kifley A, Wang JJ, et al. Role of nearwork in myopia: findings in a sample of Australian school children. Investigative Ophthalmology and Visual Science. 2008;49(7):2903-10.

16. Saw SM. Distance, lightning, and parental beliefs: understanding near work in epidemiologic studies of myopia. Optometry and Vision Science. 1999; 76(6):355-62.

17. Parssinen O, Lyrra A. Myopia and myopic progression among schoolchildren: a three-year follow up study. Investigative Ophthalmology and Visual Science. 1993;34(9):2799-802. 